\title{
High-Density Lipoprotein Mimetic Peptide 4F Efficiently Crosses the Blood-Brain Barrier and Modulates Amyloid- $\beta$ Distribution between Brain and Plasma
}

\author{
Suresh K. Swaminathan, ${ }^{1}$ Andrew L. Zhou, ${ }^{1}$ Kristen M. Ahlschwede, Geoffry L. Curran, \\ Val J. Lowe, Ling Li, and Karunya K. Kandimalla \\ Department of Pharmaceutics and Brain Barriers Research Center (S.K.S., A.L.Z., K.M.A., K.K.K.) and Department of \\ Experimental and Clinical Pharmacology (L.L.), University of Minnesota, College of Pharmacy, Minneapolis, Minnesota; \\ Department of Pharmaceutical Sciences, College of Pharmacy, Rosalind Franklin University of Medicine and Science, North \\ Chicago, Illinois (K.M.A.); and Departments of Radiology (G.L.C., V.J.L.) and Neurology (G.L.C.), Mayo Clinic, College of \\ Medicine, Rochester, Minnesota
}

Received March 3, 2020; accepted July 24, 2020

\begin{abstract}
Treatments to elevate high-density lipoprotein (HDL) levels in plasma have decreased cerebrovascular amyloid $-\beta(\mathrm{A} \beta)$ deposition and mitigated cognitive decline in Alzheimer disease (AD) transgenic mice. Since the major protein component of HDL particles, apolipoprotein A-I (ApoA-I), has very low permeability at the blood-brain barrier (BBB), we investigated $4 \mathrm{~F}$, an 18-amino-acid ApoA-I/HDL mimetic peptide, as a therapeutic alternative. Specifically, we examined the BBB permeability of $4 \mathrm{~F}$ and its effects on $\left.{ }^{125} \mathrm{I}\right] \mathrm{A} \beta$ trafficking from brain to blood and from blood to brain. After systemic injection in mice, the BBB permeability of $\left.{ }^{125} \mathrm{l}\right] 4 \mathrm{~F}$, estimated as the permeabilitysurface area (PS) product, ranged between 2 and $5 \times 10^{-6} \mathrm{ml} / \mathrm{g}$ per second in various brain regions. The PS products of $\left[{ }^{125} \mathrm{l}\right] 4 \mathrm{~F}$ were $\sim 1000$-fold higher compared with those determined for $\left[{ }^{125} \mathrm{I}\right] \mathrm{ApoA}-\mathrm{I}$. Moreover, systemic infusion with 4F increased the brain efflux of intracerebrally injected $\left[{ }^{125} \mathrm{I}\right] \mathrm{A} \beta 42$. Conversely, $4 \mathrm{~F}$ infusion decreased the brain influx of systemically injected $\left[{ }^{125} \mathrm{l}\right] \mathrm{A} \beta 42$. Interestingly, 4F did not significantly alter the brain influx of ${ }^{125}$ I]A $\beta 40$. To corroborate the in vivo findings, we evaluated the effects of $4 \mathrm{~F}$ on $\left[{ }^{125} \mathrm{I}\right] \mathrm{A} \beta 42$ transcytosis across
\end{abstract}

polarized human BBB endothelial cell (hCMEC/D3) monolayers. Treatment with 4F increased the abluminal-to-luminal flux and decreased the luminal-to-abluminal flux of $\left[{ }^{125} \mid\right] A \beta 42$ across the hCMEC/D3 monolayers. Additionally, 4F decreased the endothelial accumulation of fluorescein-labeled $A \beta 42$ in the hCMEC/D3 monolayers. These findings provide a mechanistic interpretation for the reductions in brain $A \beta$ burden reported in $A D$ mice after oral $4 \mathrm{~F}$ administration, which represents a novel strategy for treating $A D$ and cerebral amyloid angiopathy.

\section{SIGNIFICANCE STATEMENT}

The brain permeability of the ApoA-I mimetic peptide 4F was estimated to be $\sim 1000$-fold greater than ApoA-I after systemic injection of radiolabeled peptide/protein in mice. Further, 4F treatment increased the brain efflux of amyloid $-\beta$ and also decreased its brain influx, as evaluated in mice and in bloodbrain barrier cell monolayers. Thus, 4F represents a potential therapeutic strategy to mitigate brain amyloid accumulation in cerebral amyloid angiopathy and Alzheimer disease.

\section{Introduction}

Toxic amyloid- $\beta(\mathrm{A} \beta)$ peptides generated in the brain accumulate as senile plaques in the brain parenchyma, constituting one of the pathologic hallmarks of Alzheimer disease (AD). In around half of individuals over 60 years of

This work was supported by the Minnesota Partnership for Biotechnology and Medical Genomics [Grant RF1-00056030] and by National Institutes of Health National Institute on Aging [Grant RF1-AG058081] and [Grant R21AG056025]

${ }^{1}$ S.K.S. and A.L.Z. contributed equally to this work

https://doi.org/10.1124/jpet.120.265876. age and in $95 \%$ of patients with $\mathrm{AD}, \mathrm{A} \beta$ also accumulates in the cerebral vasculature, which culminates in cerebral amyloid angiopathy (CAA) (Herzig et al., 2006; Charidimou et al., 2012; Yamada and Naiki, 2012). CAA triggers cerebrovascular inflammation and represents the major cause of intracerebral hemorrhages, which lead to rapid decline in cognitive and neurologic functions in older subjects with and without AD pathology (Viswanathan and Greenberg, 2011; Charidimou et al., 2012). The two major $\mathrm{A} \beta$ isoforms associated with $\mathrm{CAA}$ and $\mathrm{AD}$ are $\mathrm{A} \beta 40$ and $\mathrm{A} \beta 42$, respectively, which differ by the presence of two additional amino acids on the $\mathrm{C}$-terminus. $\mathrm{A} \beta 40$ is considered to be the

ABBREVIATIONS: A $\beta$, amyloid- $\beta$; ABCA1, ATP-binding cassette transporter A1; AD, Alzheimer disease; A-L, abluminal-to-luminal; ApoA-I, apolipoprotein A-I; AUC, area under the curve; BBB, blood-brain barrier; CAA, cerebral amyloid angiopathy; CVD, cardiovascular disease; F-A $\beta 40$, fluorescein-labeled $A \beta 40$; F-A $\beta 42$, fluorescein-labeled A $\beta 42$; hCMEC/D3, human cerebral microvascular endothelial cell; HDL, high-density lipoprotein; L-A, luminal-to-abluminal; LRP1, low-density lipoprotein receptor-related protein 1; PS, permeability-surface area product; SR-B1, scavenger receptor class $B$ type 1; TCA, trichloroacetic acid. 
more vasculotropic isoform, whereas $\mathrm{A} \beta 42$ is considered to be more neurotoxic and amyloidogenic (Qi and Ma, 2017). The blood-brain barrier (BBB) maintains a dynamic equilibrium between brain and plasma $\mathrm{A} \beta$ pools. Along with perivascular drainage, the $\mathrm{BBB}$ participates in $\mathrm{A} \beta$ clearance from the brain. Disruption of these spatially coordinated $\mathrm{A} \beta$ clearance portals is believed to cause anomalous $\mathrm{A} \beta$ accumulation in the brain parenchyma and in the cerebral vasculature (Michaud et al., 2013a,b). The use of pharmacological agents to remodel $\mathrm{A} \beta$ trafficking mechanisms at the $\mathrm{BBB}$ and promote $\mathrm{A} \beta$ clearance from the brain could therefore improve vascular health and mitigate cognitive decline in CAA and AD.

It is well established that high-density lipoprotein (HDL) particles in plasma help to mitigate the formation of atherosclerotic plaques, thereby protecting from cardiovascular disease (CVD) (Assmann and Gotto, 2004). Emerging evidence also suggests that HDL is important for cerebrovascular and neurobiological functions (Hottman et al., 2014; Button et al., 2019). The major protein constituent of HDL particles in the periphery, apolipoprotein A-I (ApoA-I), was shown to mitigate age-related cognitive decline in $\mathrm{AD}$ transgenic mice by us (Lewis et al., 2010) and others (Lefterov et al., 2010). These two studies established that ApoA-I overexpression reduces cerebrovascular $\mathrm{A} \beta$ deposition (CAA) and attenuates $\mathrm{A} \beta$ associated neuroinflammation (Lewis et al., 2010), whereas ApoA-I deletion exacerbates CAA in the $\mathrm{AD}$ transgenic mice (Lefterov et al., 2010). Intriguingly, genetic manipulation of ApoA-I expression did not alter parenchymal $\mathrm{A} \beta$ deposition (Fagan et al., 2004; Lefterov et al., 2010; Lewis et al., 2010). Recently, we reported that radioiodinated ApoA-I displays very low brain permeability in Sprague-Dawley rats after systemic injection (Zhou et al., 2019). Since ApoA-I is almost exclusively expressed in the periphery, the absence of effects on parenchymal $\mathrm{A} \beta$ deposition could potentially be attributed to the low brain permeability of ApoA-I.

Despite the well documented cardio-, neuro-, and vasoprotective effects of ApoA-I, therapeutic applications are limited by its poor oral bioavailability, high manufacturing costs, and low brain permeability. To address these limitations, small peptides that mimic ApoA-I/HDL function have been developed (Navab et al., 2010). The most notable of these HDL mimetics is the 18 -amino-acid peptide " $4 \mathrm{~F}$," which contains four phenylalanine residues (Ac-DWFKAFYDKVAEKFKEAF- $\mathrm{NH}_{2}$ ) and was designed to mimic the amphipathic $\alpha$-helix motif present in ApoA-I, which is important for its biologic activity (Anantharamaiah et al., 2007). Oral administration of $4 \mathrm{~F}$ was shown to reduce atherosclerotic lesions and plaque inflammation in a diabetes mouse model (Morgantini et al., 2010). Treatment with $4 \mathrm{~F}$ was also shown to decrease cerebrovascular inflammation and improve cognitive function in a mouse model of atherosclerosis (Buga et al., 2006). Moreover, oral administration of $4 \mathrm{~F}$ together with a statin drug reduced $\mathrm{A} \beta$ deposition in the brain parenchyma, ameliorated $\mathrm{A} \beta$-associated neuroinflammation, and improved cognitive function in an $\mathrm{AD}$ transgenic mouse model (Handattu et al., 2009).

These literature reports suggest that $4 \mathrm{~F}$ could potentially be employed as a therapeutic agent to mitigate sporadic CAAand AD-related neurovascular pathologies. However, the brain penetrance of $4 \mathrm{~F}$ has not been established, and the mechanisms by which $4 \mathrm{~F}$ influences parenchymal and cerebrovascular $\mathrm{A} \beta$ deposition are poorly understood. Here, we assessed the permeability of radioiodinated $4 \mathrm{~F}$ versus ApoA-I at various brain regions after systemic injection in mice. Additionally, we examined the effects of $4 \mathrm{~F}$ on both the brain efflux and brain influx of radioiodinated $\mathrm{A} \beta$ peptides. The in vivo findings were further supported by complementary studies conducted in BBB cell monolayers.

\section{Materials and Methods}

Animals. Wild-type mice (B6SJLF1/J) were bred in-house at the Mayo Clinic animal facilities. Animals were raised with food and water ad libitum with 12-hour light/dark cycles. Animal studies were carried out in accordance with the guide for the care and use of laboratory animals provided by the National Institutes of Health. All protocols were approved by the Mayo Clinic Institutional Animal Care and Use Committee. All studies were conducted using female mice between 8 and 12 months of age and weighing approximately $30 \mathrm{~g}$.

Radioiodination of 4F, ApoA-I, and A $\beta$ Peptides. The following peptides/proteins were labeled with ${ }^{125} \mathrm{I}$ (PerkinElmer Life and Analytical Sciences, Boston, MA) using the chloramine-T reaction as described previously (Poduslo et al., 2001; Jaruszewski et al., 2014): D$4 \mathrm{~F}$ peptide [American Peptide Company (now Bachem), Sunnyvale, $\mathrm{CA}$ ], human serum-derived ApoA-I (EMD Millipore, Burlington, MA), and $\mathrm{A} \beta 42$ and $\mathrm{A} \beta 40$ peptides (custom synthesized by AAPPTec, Louisville, KY, or Mayo Clinic proteomics core facility). The unconjugated ${ }^{125} \mathrm{I}$ was removed by dialysis overnight in PBS, and the purity of the radiolabeled proteins was determined by trichloroacetic acid (TCA) precipitation as described previously (Kandimalla et al., 2007). The specific activity of labeled $\mathrm{A} \beta$ peptides was determined to be $40 \mu \mathrm{Ci} / \mu \mathrm{g}$.

Brain Influx of $\left[{ }^{125} I\right] 4 F$ Versus $\left[{ }^{125} I\right] A p o A-I$ after Systemic Injection. These assays were conducted as described in our previous publications (Swaminathan et al., 2018). Briefly, mice were anesthetized under a mixture of isoflurane (1.5\%) and oxygen (4 1/min) and then catheterized at the femoral vein and artery $(n=4)$. A bolus of $\left[{ }^{125} \mathrm{I}\right] 4 \mathrm{~F}(100 \mu \mathrm{Ci} ; 11 \mathrm{nmol})$ or $\left[{ }^{125} \mathrm{I}\right] \mathrm{ApoA}-\mathrm{I}(100 \mu \mathrm{Ci} ; 0.88 \mathrm{nmol})$ was injected into the femoral vein, and then $20-\mu$ l blood samples were collected from the femoral artery at $0.25,1,3,5,10$, and 15 minutes using heparinized capillary tubes. The blood samples were diluted with saline and centrifuged to separate the plasma. The $\left[{ }^{125} \mathrm{I}\right] 4 \mathrm{~F}$ or $\left[{ }^{125} \mathrm{I}\right]$ ApoA-I in plasma was precipitated by using TCA and was centrifuged to collect the pellet. Total ${ }^{125}$ I radioactivity counts in the pellet, corresponding to intact peptide/protein, were measured using a gamma counter (Cobra II; Amersham Biosciences, Piscataway, NJ). Immediately after the final sampling event, the mice were euthanized by transcardial perfusion with excess PBS to flush the remaining radioactivity from the vasculature. Individual brain regions (cortex, caudate putamen, hippocampus, thalamus, brain stem, and cerebellum) were dissected and assayed for ${ }^{125} \mathrm{I}$ radioactivity using a gamma counter.

The influx of $\left[{ }^{125} \mathrm{I}\right] 4 \mathrm{~F}$ and $\left[{ }^{125} \mathrm{I}\right] \mathrm{ApoA}-\mathrm{I}$ at each brain region was assessed as the permeability-surface area (PS) product. The PS product (milliliter per gram per second) at each brain region was determined using the equation

$$
P S=\frac{q(t)}{\int_{0}^{t} C_{p} d t}
$$

where $q(t)$ is the extravascular amount of $\left[{ }^{125} \mathrm{I}\right] 4 \mathrm{~F}$ or $\left[{ }^{125} \mathrm{I}\right] \mathrm{ApoA}-\mathrm{I}$ in the brain region per gram of tissue $(\mu \mathrm{Ci} / \mathrm{g})$ at the end of the experiment, and $\int_{0}^{t} C_{p} d t$ is the area under the plasma concentration versus time profile (minute $\times$ microcurie per milliliter) from 0 to 15 minutes, calculated using the linear-trapezoidal method.

Impact of 4F on the Brain-To-Blood Efflux of $\left[{ }^{125} \mathrm{I}\right] \mathrm{A} \beta 42$. Mice were anesthetized as described above, and the left internal carotid artery was catheterized. Immediately afterward, mice were mounted on a stereotaxic apparatus. The skin above the skull was cut open, and sutures were exposed. As per the accurate stereotaxic coordinates, 
a small hole was drilled into the skull directly above the hippocampus. The animals were infused over 60 minutes with or without $2 \mathrm{mg}(0.9$ $\mu \mathrm{mol}$ ) of $4 \mathrm{~F}$ peptide dissolved in $200 \mu \mathrm{l}$ of saline ( $n=3$ each group) via the left internal carotid artery, which supplies blood directly to the left hemisphere and thereby allows for greater $4 \mathrm{~F}$ exposure to the BBB. At the end of the infusion, the mice were injected with $\left[{ }^{125} \mathrm{I}\right] \mathrm{A} \beta 42(0.7$ $\mu \mathrm{Ci})$ dissolved in PBS $(1 \mu \mathrm{l})$ directly into the right hippocampus. After 40 minutes post-A $\beta$ injection, the animals were transcardially perfused with excess PBS. Brain hemispheres were dissected and assayed for ${ }^{125} \mathrm{I}$ radioactivity using a gamma counter. The measured brain radioactivity per gram of tissue was normalized to the radioactivity measured at the site of injection using the following equation:

$$
\begin{aligned}
& \text { Brain }- \text { to }- \text { Blood Efflux } \\
& =\frac{\text { Radioactivity per gram of brain tissue }\left(\frac{\mu C i}{\mathrm{~g}}\right)}{\text { Radioactivity at the injection site }\left(\frac{\mu C i}{\mathrm{~g}}\right)} .
\end{aligned}
$$

Impact of 4F on the Blood-to-Brain Influx of $\left[{ }^{125} \mathrm{I}\right] \mathrm{A} \beta 42$ and $\left[{ }^{125} \mathbf{I}\right] \mathbf{A} \boldsymbol{\beta} 40$. These assays were conducted as described in our previous publications (Swaminathan et al., 2018). Briefly, mice were anesthetized, and the femoral vein, femoral artery, and left internal carotid artery were catheterized. The animals were then infused with saline $(200 \mu \mathrm{l})$ with or without $2 \mathrm{mg}(0.9 \mu \mathrm{mol})$ of $4 \mathrm{~F}$ peptide via the left internal carotid artery over a period of 60 minutes. After this, the animals were bolus-injected with $100 \mu \mathrm{Ci}$ of $\left[{ }^{125} \mathrm{I}\right] \mathrm{A} \beta 42$ or $\left[{ }^{125} \mathrm{I}\right] \mathrm{A} \beta 40$ into the femoral vein ( $n=3$ each group). Blood samples of $20 \mu$ l were collected from the femoral artery at $0.25,1,3,5,10$, and 15 minutes post-A $\beta$ injection. After separating the plasma, the intact $\left[{ }^{125} \mathrm{I}\right] \mathrm{A} \beta 42$ or $\left[{ }^{125} \mathrm{I}\right] \mathrm{A} \beta 40$ in plasma was precipitated using TCA and then centrifuged. Total ${ }^{125} \mathrm{I}$ radioactivity counts in the pellet were measured using a gamma counter. Immediately after the final sampling event, the animals were transcardially perfused with PBS, the brain regions were dissected, and the ${ }^{125} \mathrm{I}$ radioactivity was measured by using a gamma counter. The PS products for $\left[{ }^{125} \mathrm{I}\right] \mathrm{A} \beta 42$ and $\left[{ }^{125} \mathrm{I}\right] \mathrm{A} \beta 40$ at the hippocampus and the left hemisphere were determined as described above for $\left.{ }^{[25} \mathrm{I}\right] 4 \mathrm{~F}$.

Impact of $4 F$ on $\left[{ }^{125} I\right] A \beta 42$ and $\left[{ }^{125} I\right] A \beta 40$ Plasma Pharmacokinetics. The $\left[{ }^{125} \mathrm{I}\right] \mathrm{A} \beta 42$ and $\left[{ }^{125} \mathrm{I}\right] \mathrm{A} \beta 40$ plasma concentration versus time data from 0 to 15 minutes were evaluated by noncompartmental analysis using Phoenix WinNonlin (Certara). Parameters of interest included the area under the concentration versus time profile from 0 to 15 minutes $\left(\mathrm{AUC}_{0-\mathrm{t}}\right.$; minute $\times$ microcurie per milliliter) and the terminal clearance (milliliter per minute).

Cell Culture. The immortalized human cerebral microvascular endothelial cell line (hCMEC/D3) was generously provided by PerrieOliver Couraud, Institut Cochin, France (Weksler et al., 2013). The cells were grown at $37^{\circ} \mathrm{C}$ under $5 \% \mathrm{CO}_{2}$ atmosphere on rat tail collagen (Corning, Corning, NY)-coated cell culture-grade flasks (Corning) using endothelial basal media-2 (Lonza, Walkersville, MD) supplemented with 5\% FBS (Atlanta Biologicals, Flowery Branch, GA), $1 \%$ penicillin-streptomycin (Corning), $1.4 \mu \mathrm{M}$ hydrocortisone (SigmaAldrich, St Louis, MO), ascorbic acid (5 $\mu \mathrm{g} / \mathrm{ml}$; Sigma-Aldrich), $1 \%$ chemically defined lipid concentrate (Life Technologies, Grand Island, NY), $10 \mathrm{mM}$ HEPES, and $1 \mathrm{ng} / \mathrm{ml}$ basic fibroblast growth factor (Peprotech, Rocky Hill, NJ). Cells in passages 27-35 were used in the experiments.

Impact of $4 F$ on the Abluminal-to-Luminal Versus Luminal-to-Abluminal Flux of Radioiodinated A $\beta$ Across BBB Cell Monolayers. These experiments were performed as described in our previous publications (Agyare et al., 2013). Briefly, the hCMEC/D3 cells were cultured on $12-\mathrm{mm}$ Transwell inserts with $0.4-\mu \mathrm{m}$ pores (Corning) until a continuous monolayer was formed. The monolayer integrity was verified by measuring the transendothelial electrical resistance. Experiments were conducted when transendothelial electrical resistance values ranged between 80 and $120 \Omega / \mathrm{cm}^{2}$. The evening before the experiment, the growth medium containing $5 \% \mathrm{FBS}$ and $10 \mathrm{mM}$ HEPES was replaced with growth medium containing $1 \%$ FBS and $20 \mathrm{mM}$ HEPES. To investigate abluminal-toluminal (A-L) transport, cells were pretreated with or without $4 \mathrm{~F}$ (10 $\mu \mathrm{g} / \mathrm{ml})$ on the abluminal side for 60 minutes at $37^{\circ} \mathrm{C}(n=4$ in each group). Without removing $4 \mathrm{~F},\left[{ }^{125} \mathrm{I}\right] \mathrm{A} \beta 42(10 \mu \mathrm{Ci} / \mathrm{ml})$ was then spiked into the abluminal medium. The luminal medium was then sampled $(20 \mu \mathrm{l})$ at $10,20,30,45,60$, and 90 minutes post-A $\beta$ addition, and the ${ }^{125}$ I radioactivity was measured using a gamma counter. Similar studies were conducted to investigate luminal-to-abluminal (L-A) transport, with $4 \mathrm{~F}$ preincubation and $\left[{ }^{125} \mathrm{I}\right] \mathrm{A} \beta 42$ addition occurring on the luminal side, followed by sampling from the abluminal side. The cumulative amount of radioactivity reaching the contralateral side was plotted against time. The slope obtained after linear regression of the linear region of the curve, in which unidirectional transfer is assumed, was divided by the surface area of the Transwell insert $\left(1.12 \mathrm{~cm}^{2}\right)$ to calculate $\left.{ }^{[125} \mathrm{I}\right] \mathrm{A} \beta 42$ flux across the monolayer.

Impact of $4 \mathrm{~F}$ on the Accumulation of Fluorescein-Labeled $\mathbf{A \beta 4 2}$ and $\mathbf{A \beta 4 0}$ in BBB Cell Monolayers. For flow cytometry studies, hCMEC/D3 cells were cultured on six-well plates (Corning) until a continuous monolayer was formed. The evening before the experiment, the growth medium containing $5 \%$ FBS was replaced with growth medium containing $1 \%$ FBS. Cells were pretreated with or without $4 \mathrm{~F}(10 \mu \mathrm{g} / \mathrm{ml})$ for 60 minutes at $37^{\circ} \mathrm{C}$ ( $n=3$ in each group). After this, fluorescein-labeled $\mathrm{A} \beta 42$ (F-A $\beta 42$ ) or F-A $\beta 40$ (synthesized by the Mayo Clinic proteomics core facility) was spiked into the media $(1.5 \mu \mathrm{g} / \mathrm{ml})$ and then further incubated for 60 minutes. Cells were washed three times with ice-cold PBS, trypsinized, and then resuspended in PBS followed by 1:1 dilution with $4 \%$ paraformaldehyde on ice. Cellular uptake of the fluorescence signal was measured using LSR-II Fortessa flow cytometry equipped with a $20-\mathrm{mW}(488 \mathrm{~nm})$ laser (BD Biosciences, San Jose, CA). Data analysis was performed using FlowJo software (TreeStar, Inc., San Carlos, CA).

For confocal microscopy studies, hCMEC/D3 cells were cultured on 35-mm coverslip bottom dishes (MatTek, Ashland, MA) until a continuous monolayer was formed. The evening before the experiment, the growth medium containing $5 \%$ FBS was replaced with growth medium containing $1 \% \mathrm{FBS}$. Cells were pretreated with or without $4 \mathrm{~F}(10 \mu \mathrm{g} / \mathrm{ml})$ for 60 minutes at $37^{\circ} \mathrm{C}$ ( $n=3$ in each group). After this, $\mathrm{F}-\mathrm{A} \beta 42$ was spiked into the media $(1.5 \mu \mathrm{g} / \mathrm{ml})$ and then further incubated for 60 minutes. Cells were washed three times with ice-cold PBS, fixed in $4 \%$ paraformaldehyde for 60 minutes on ice, and then mounted with ProLong Diamond mounting media containing 4',6-diamidino2-phenylindole (Invitrogen). Cell monolayers were imaged using a Zeiss LSM 780 laser confocal microscope using a C-Apochromat $40 \times / 1.2$-W objective.

Statistical Analysis. All statistical tests were conducted using GraphPad Prism (GraphPad software, La Jolla, CA). A $P$ value of $<$ 0.05 was considered statistically significant. One-way ANOVA with Tukey's post-tests were used to compare the $\left[{ }^{125} \mathrm{I}\right] 4 \mathrm{~F}$ versus $\left[{ }^{125} \mathrm{I}\right]$ ApoA-I distribution in various brain regions. Unpaired, two-tailed $t$ tests were used to compare the $\left[{ }^{125} \mathrm{I}\right] \mathrm{A} \beta$ distribution in the brain or plasma in mice, the $\left[{ }^{125} \mathrm{I}\right] \mathrm{A} \beta$ flux in vitro, and the $\mathrm{F}-\mathrm{A} \beta$ uptake in vitro in groups with versus without $4 \mathrm{~F}$ treatment.

\section{Results}

Brain Influx of $\left[{ }^{125} \mathrm{I}\right] 4 \mathrm{~F}$ Is Substantially Higher than [125I]ApoA-I. After femoral injection, the permeability of $\left[{ }^{125} \mathrm{I}\right] 4 \mathrm{~F}$ and $\left[{ }^{125} \mathrm{I}\right] \mathrm{ApoA}-\mathrm{I}$ at each brain region was determined as the PS product, which was obtained by dividing the total radioactivity per gram tissue by the plasma $\mathrm{AUC}_{0-\mathrm{t}}$ (Fig. 1A). The $\left[{ }^{125} \mathrm{I}\right] 4 \mathrm{~F}$ permeability at various brain regions ranged from 2 to $5 \times 10^{-6} \mathrm{ml} / \mathrm{g}$ per second, which was $\sim 1000$-fold greater $(P<0.0001$, one-way ANOVA with Tukey's post-tests $)$ compared with the $\left[{ }^{125} \mathrm{I}\right]$ ApoA-I permeability, which ranged from 2 to $12 \times 10^{-9} \mathrm{ml} / \mathrm{g}$ per second at various brain regions (Fig. 1B). 
A

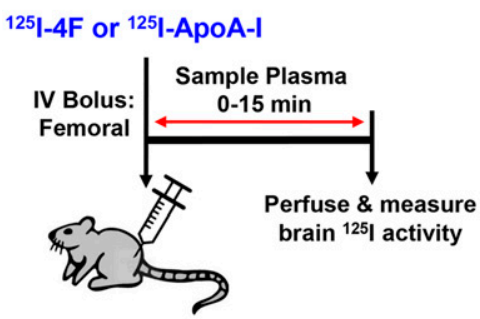

B

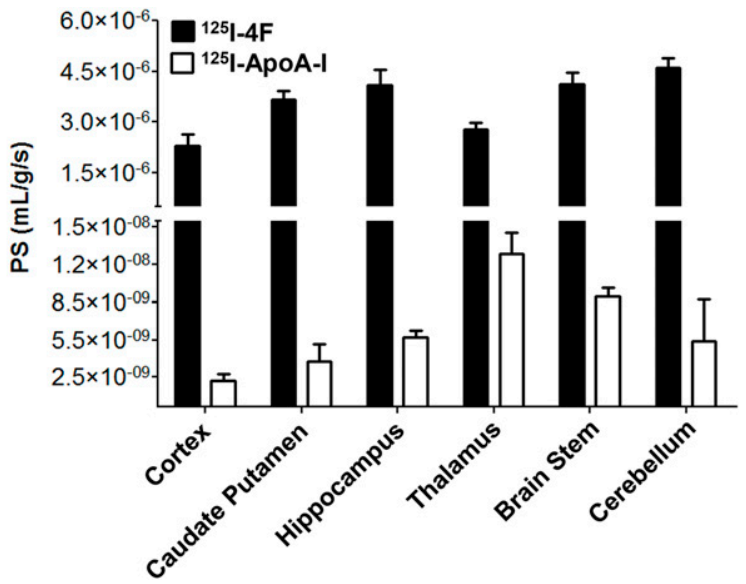

Fig. 1. Brain influx of $\left[{ }^{125} \mathrm{I}\right] 4 \mathrm{~F}$ is substantially higher than $\left[{ }^{125} \mathrm{I}\right]$ ApoA-I. (A) Experimental scheme. B6SJLF1/J mice were bolus-injected with $100 \mu \mathrm{Ci}$ of $\left[{ }^{125} \mathrm{I}\right]$ $4 \mathrm{~F}$ or $\left[{ }^{125} \mathrm{I}\right] \mathrm{ApoA}-\mathrm{I}$ via the femoral vein. Blood was sampled periodically from the femoral artery from 0 to 15 minutes. The plasma was separated, the intact protein was precipitated with TCA, and the radioactivity was measured. After the final sampling event, mice were transcardially perfused with excess PBS, brain regions were dissected, and the radioactivity was measured. (B) The $\left.{ }^{125} \mathrm{I}\right] 4 \mathrm{~F}$ vs. $\left[{ }^{125} \mathrm{I}\right] \mathrm{ApoA}-\mathrm{I}$ PS product estimates are shown for various brain regions. Data represent means \pm S.D $(n=4)$. $* * * P<0.0001$; one-way ANOVA.
4F Promotes the Brain Efflux of $\left[{ }^{125} \mathrm{I}\right] \mathrm{A} \beta 42$. After infusion with saline or $4 \mathrm{~F}(2 \mathrm{mg})$ via the internal carotid artery, $\left[{ }^{125} \mathrm{I}\right] \mathrm{A} \beta 42(0.7 \mu \mathrm{Ci})$ was stereotaxically injected into the right hippocampus. After 40 minutes, the ${ }^{125}$ I radioactivity retained in the brain was measured and normalized to the radioactivity at the site of injection (Fig. 2). In mice infused with $4 \mathrm{~F}$, the retention of $\left[{ }^{125} \mathrm{I}\right] \mathrm{A} \beta 42$ in the whole brain $(1.7 \pm$ 0.2 , means \pm S.D., $n=3)$ was decreased by $\sim 2$-fold $(P<$ 0.05 , two-tailed $t$ test) compared with mice infused with saline control $(4.0 \pm 1.2$, means \pm S.D., $n=3)$. Similar trends were observed for the right hemisphere, in which the $\left[{ }^{125} \mathrm{I}\right] \mathrm{A} \beta 42$ retention was decreased $(P<0.05$, two-tailed $t$ test) in the $4 \mathrm{~F}$ infused mice $(1.6 \pm 0.2)$ compared with the saline control $(2.9 \pm 0.6)$. The observed decrease in brain retention is reflective of increased brain efflux.
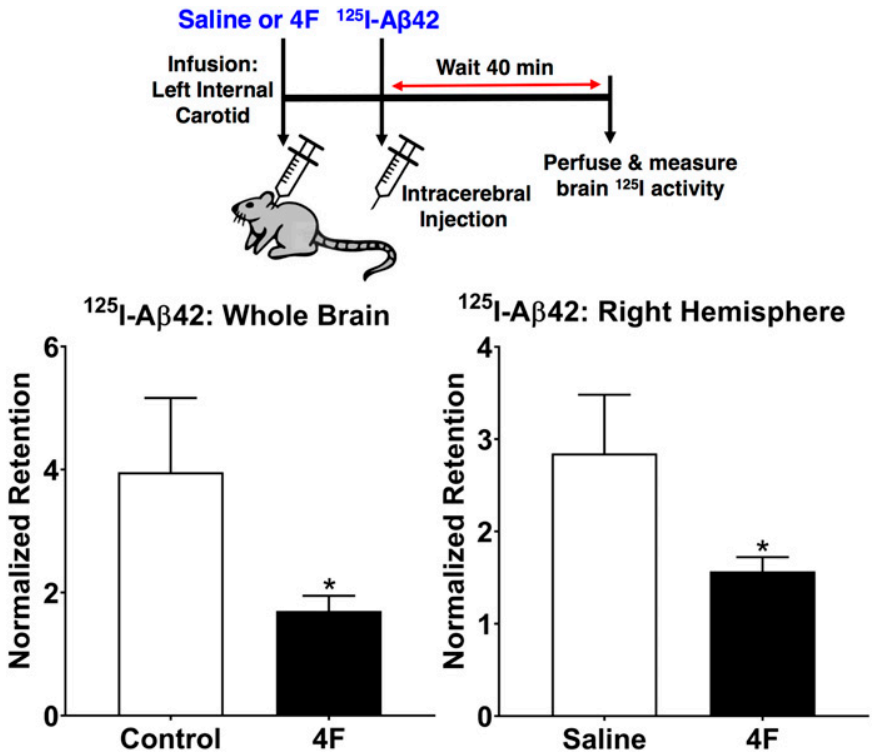

Fig. 2. $4 \mathrm{~F}$ promotes the brain efflux of $\left[{ }^{125} \mathrm{I}\right] \mathrm{A} \beta 42$. Mice were infused with saline or $4 \mathrm{~F}(2 \mathrm{mg})$ via the left internal carotid artery over a period of 60 minutes. At the end of infusion, $\left.{ }^{[25} \mathrm{I}\right] \mathrm{A} \beta 42(0.7 \mu \mathrm{Ci})$ was stereotaxically injected into the right hippocampus. After 40 minutes, the mice were transcardially perfused with excess PBS, and the radioactivity retained in the whole brain and right hemisphere was measured. The bar charts indicate the radioactivity in whole brain or right hemisphere relative to the radioactivity at the injection site. Data represent means \pm S.D. $(n=3)$. $* P<0.05$; unpaired two-tailed $t$ test.
4F Inhibits the Brain Influx of $\left[{ }^{125} \mathrm{I}\right] \mathrm{A} \beta 42$ but Not $\left[{ }^{125} \mathrm{I}\right] \mathbf{A} \boldsymbol{\beta} 40$. The influx of $\left[{ }^{125} \mathrm{I}\right] \mathrm{A} \beta 42$ and $\left[{ }^{125} \mathrm{I}\right] \mathrm{A} \beta 40$ into the brain after femoral injection was assessed as the PS product, determined using the methods described above for $\left[{ }^{125} \mathrm{I}\right] 4 \mathrm{~F}$. In mice infused with $4 \mathrm{~F}$, the influx of $\left[{ }^{125} \mathrm{I}\right] \mathrm{A} \beta 42$ into the hippocampus $\left(0.34 \pm 0.09 \times 10^{-4} \mathrm{ml} / \mathrm{g}\right.$ per second, means \pm S.D., $n=3$ ) decreased by $\sim 4$-fold ( $P<0.0001$, two-tailed $t$ test) compared with mice infused with saline control $(1.3 \pm$ $0.2 \mathrm{ml} / \mathrm{g}$ per second $\times 10^{-4}$, means \pm S.D., $n=3$ ) (Fig. 3A). The hippocampus is the brain region most severely compromised in Alzheimer disease (Smith, 2002). The A $\beta$ influx into the individual brain hemispheres was also evaluated. In mice infused with $4 \mathrm{~F}$, the influx of $\left[{ }^{125} \mathrm{I}\right] \mathrm{A} \beta 42$ into the left hemisphere $\left(0.54 \pm 0.16 \times 10^{-4} \mathrm{ml} / \mathrm{g}\right.$ per second $)$ decreased by $\sim 2$-fold ( $P<0.05$, two-tailed $t$ test) compared with mice infused with saline control $\left(1.1 \pm 0.3 \times 10^{-4} \mathrm{ml} / \mathrm{g}\right.$ per second $)$ (Fig. 3B). In contrast, a nonsignificant increase $(P=0.13$, twotailed $t$ test) in $\left[{ }^{125} \mathrm{I}\right] \mathrm{A} \beta 40$ influx into the left hemisphere was observed in the $4 \mathrm{~F}$-infused mice $\left(1.4 \pm 0.8 \times 10^{-4} \mathrm{ml} / \mathrm{g}\right.$ per second, means \pm S.D., $n=3$ ) when compared with salineinfused mice $\left(0.70 \pm 0.54 \times 10^{-4} \mathrm{ml} / \mathrm{g}\right.$ per second, means \pm S.D., $n=3$ ) (Fig. 3C).

Impact of $4 \mathrm{~F}$ on $\left[{ }^{125} \mathrm{I}\right] \mathrm{A} \beta 42$ and $\left[{ }^{125} \mathrm{I}\right] \mathrm{A} \beta 40$ Plasma Pharmacokinetics. The $\left[{ }^{125} \mathrm{I}\right] \mathrm{A} \beta 42$ and $\left[{ }^{125} \mathrm{I}\right] \mathrm{A} \beta 40$ plasma concentration versus time data between 0 and 15 minutes after femoral injection were evaluated by noncompartmental analysis (Fig. 4). The $\mathrm{AUC}_{0-\mathrm{t}}$ and terminal clearance of $\left[{ }^{125} \mathrm{I}\right]$ $\mathrm{A} \beta 42$ in saline-infused mice were estimated as $25.3 \pm 18.4 \mathrm{~min} \times$ $\mu \mathrm{Ci} / \mathrm{ml}$ and $4.1 \pm 2.3 \mathrm{ml} / \mathrm{min}$ (means \pm S.D., $n=3$ ), respectively. These parameters were not significantly altered in the $4 \mathrm{~F}$-infused mice and were found to be $39.5 \pm 27.6 \mathrm{~min} \times$ $\mu \mathrm{Ci} / \mathrm{ml}$ (means \pm S.D., $n=3$ ) and $2.9 \pm 1.6 \mathrm{ml} / \mathrm{min}$, respectively. For $\left[{ }^{125} \mathrm{I}\right] \mathrm{A} \beta 40$, the $\mathrm{AUC}_{0-\mathrm{t}}$ and terminal clearance in saline-infused mice were estimated as $53.3 \pm 11.7 \mathrm{~min} \times$ $\mu \mathrm{Ci} / \mathrm{ml}$ and $1.6 \pm 0.3 \mathrm{ml} / \mathrm{min}$ (means \pm S.D., $n=3$ ), respectively. These parameters were unaltered in the $4 \mathrm{~F}$-infused mice and were estimated as $49.3 \pm 16.2 \mathrm{~min} \times$ $\mu \mathrm{Ci} / \mathrm{ml}$ and $1.5 \pm 0.5 \mathrm{ml} / \mathrm{min}$ (means \pm S.D., $n=3$ ), respectively.

4F Promotes the Abluminal-to-Luminal Flux and Inhibits the Luminal-to-Abluminal Flux of $\left[{ }^{125} \mathrm{I}\right] \mathrm{A} \beta 42$ Across BBB Cell Monolayers. To corroborate the in vivo findings, further studies were conducted to examine the transport of $\left[{ }^{125} \mathrm{I}\right] \mathrm{A} \beta 42$ across hCMEC/D3 monolayers cultured on Transwell filters, a widely used in vitro BBB model (Weksler et al., 2013). The $\left[{ }^{125} \mathrm{I}\right] \mathrm{A} \beta 42$ transport was 
A
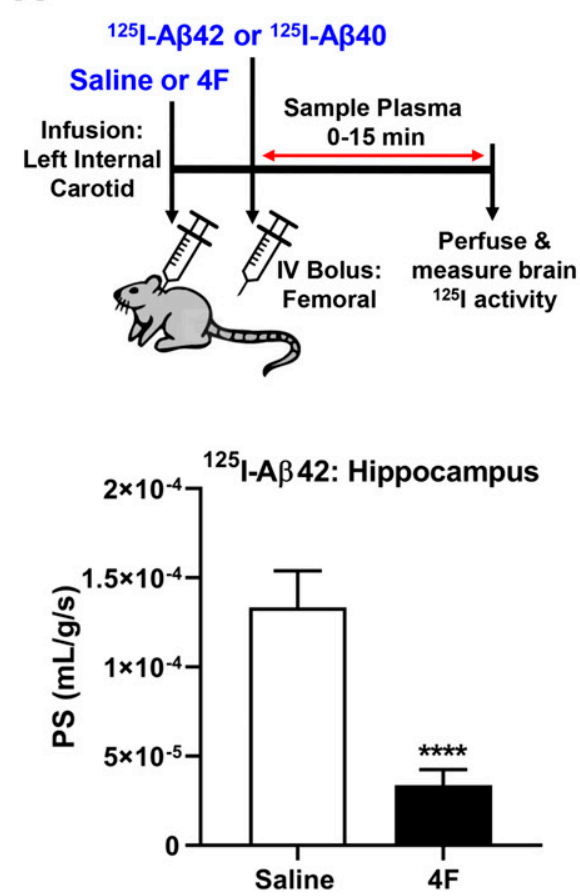

B
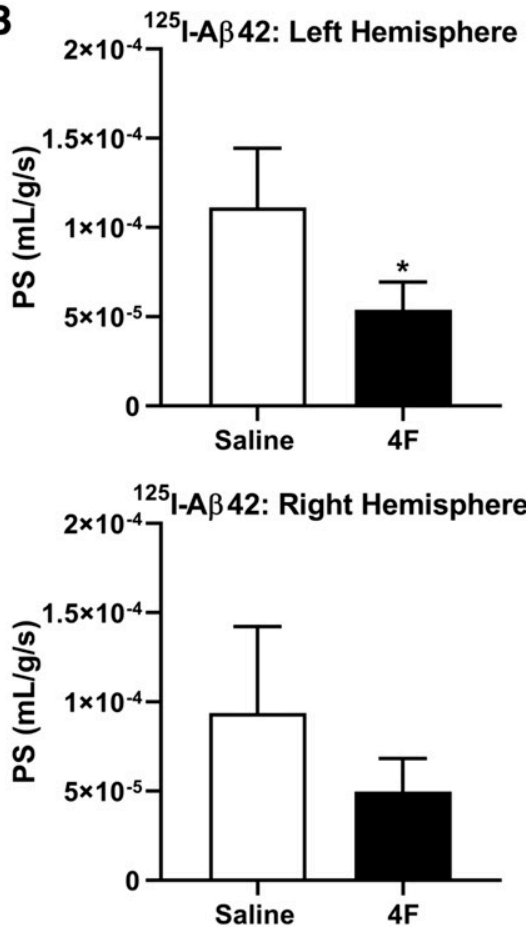
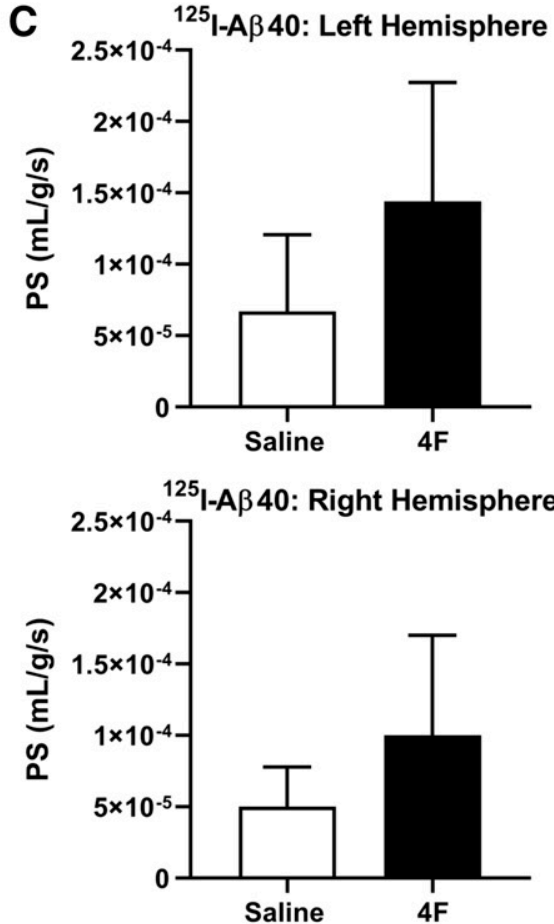

Fig. 3. $4 \mathrm{~F}$ inhibits the brain influx of $\left[{ }^{125} \mathrm{I}\right] \mathrm{A} \beta 42$ but not $\left[{ }^{125} \mathrm{I}\right] \mathrm{A} \beta 40$. (A) Experimental scheme. Mice were infused with saline or $4 \mathrm{~F}(2 \mathrm{mg})$ via the left internal carotid artery over a period of 60 minutes. After this, $100 \mu \mathrm{Ci}$ of $\left[{ }^{125} \mathrm{I}\right] \mathrm{A} \beta 42$ or $\left[{ }^{125} \mathrm{I}\right] \mathrm{A} \beta 40$ was bolus-injected via the femoral vein. Blood was sampled periodically from the femoral artery from 0 to 15 minutes. Postperfusion with PBS, the brain regions were harvested, and the radioactivity was measured. (B) The PS product estimates for $\left[{ }^{125} \mathrm{I}\right] \mathrm{A} \beta 42$ in the left/right hemispheres and hippocampus are shown. Data represent means \pm S.D. $(n=3)$. $* P<0.05$; unpaired two-tailed $t$ test. (C) The PS product estimates for $\left.{ }^{125} \mathrm{I}\right] \mathrm{A} \beta 40$ in the left/right hemispheres are shown. Data represent means \pm S.D. $(n=3) . * * * * \mathrm{p}<0.001$

investigated in both directions. To study the A-L transport (i.e., from brain to blood), cells were treated with $4 \mathrm{~F}$, and then $\left[{ }^{125} \mathrm{I}\right] \mathrm{A} \beta 42$ was added together on the abluminal side, followed by periodic sampling on the luminal side (Fig. 5A). The slope of the linear portion of the cumulative radioactivity versus time plot estimates the $\left[{ }^{125} \mathrm{I}\right] \mathrm{A} \beta 42$ flux in the A-L direction. The A-L flux was increased by $\sim 2$-fold $(P<0.05$, two-tailed $t$ test) in the $4 \mathrm{~F}$-treated cells $\left(4.9 \pm 0.4 \times 10^{-4} \mu \mathrm{Ci} / \mathrm{min}\right.$, means \pm S.D., $n=$ 4) as compared with the untreated control $\left(2.8 \pm 0.3 \times 10^{-4}\right.$ $\mu \mathrm{Ci} / \mathrm{min}$, means \pm S.D., $n=4$ ). To study the L-A transport (i.e., from blood to brain), cells were treated with $4 \mathrm{~F}$, and then $\left[{ }^{125} \mathrm{I}\right] \mathrm{A} \beta 42$ was added together on the luminal side, followed by periodic sampling on the abluminal side (Fig. 5B). The $\left[{ }^{125} \mathrm{I}\right]$ $\mathrm{A} \beta 42$ flux in the L-A direction was decreased by $\sim 2$-fold $(P<$ 0.05 , two-tailed $t$ test $)$ in the $4 \mathrm{~F}$-treated cells $\left(2.2 \pm 0.2 \times 10^{-4}\right.$ $\mu \mathrm{Ci} / \mathrm{min}$, means \pm S.D., $n=4)$ compared with the untreated control $\left(4.9 \pm 0.9 \times 10^{-4} \mu \mathrm{Ci} / \mathrm{min}\right.$, means \pm S.D., $\left.n=4\right)$.

4F Inhibits the Accumulation of Fluorescein-Labeled A $\beta 42$ in BBB Cell Monolayers. The effects of $4 \mathrm{~F}$ on the uptake of fluorescein-labeled $\mathrm{A} \beta$ (F-A $\beta$ ) in hCMEC/D3 monolayers was further investigated. Treatment with $4 \mathrm{~F}$ decreased the cellular uptake of F-A $\beta 42$ by $\sim 1.4$-fold $(P<0.05$, twotailed $t$ test) when assessed by flow cytometry (Fig. 6A). In contrast, no significant differences were observed in the cell

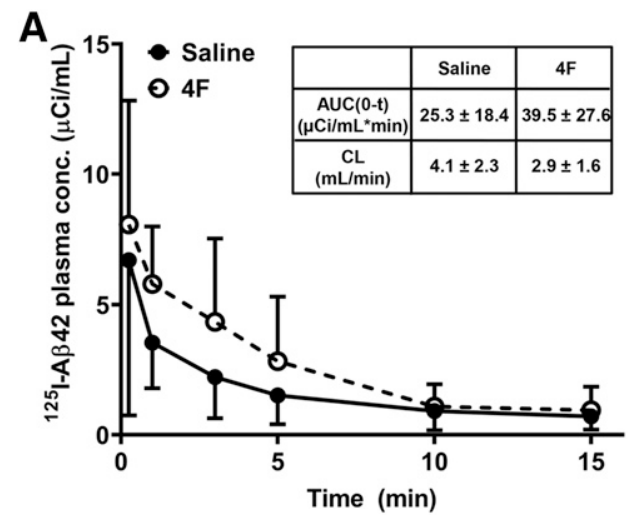

B

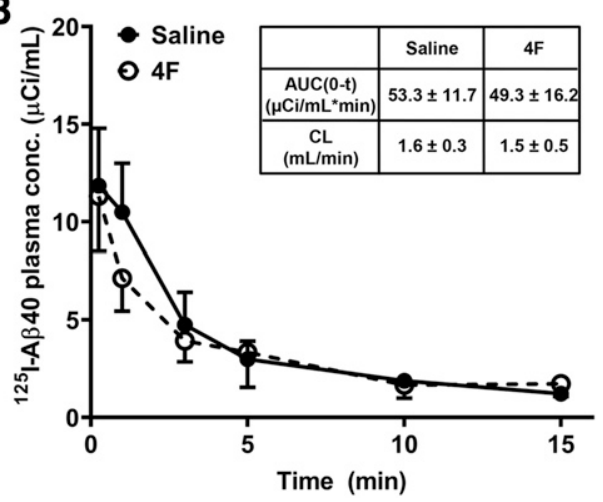

Fig. 4. Impact of $4 \mathrm{~F}$ on $\left[{ }^{125} \mathrm{I}\right] \mathrm{A} \beta 42$ and $\left[{ }^{125} \mathrm{I}\right] \mathrm{A} \beta 40$ plasma pharmacokinetics. Mice were infused with saline or $4 \mathrm{~F}(2 \mathrm{mg})$ via the left internal carotid artery over a period of 60 minutes. After this, $100 \mu \mathrm{Ci}$ of $\left[{ }^{125} \mathrm{I}\right]$ $\mathrm{A} \beta 42$ or $\left.{ }^{[25} \mathrm{I}\right] \mathrm{A} \beta 40$ was bolus-injected via the femoral vein. Blood was sampled periodically from the femoral artery between 0 and 15 minutes. The plasma was separated, the intact protein was precipitated with TCA, and the radioactivity was measured. The plasma concentration vs. time profiles for $\left[{ }^{125} \mathrm{I}\right] \mathrm{A} \beta 42(\mathrm{~A})$ and $\left[{ }^{125} \mathrm{I}\right]$ $\mathrm{A} \beta 40$ (B) were evaluated by noncompartmental analysis. Inset tables show estimates for the area under the concentration vs. time curve from 0 to 15 minutes $\left(\mathrm{AUC}_{0-\mathrm{t}}\right)$ and the terminal clearance (CL). Data represent means \pm S.D. $(n=3)$. 
A
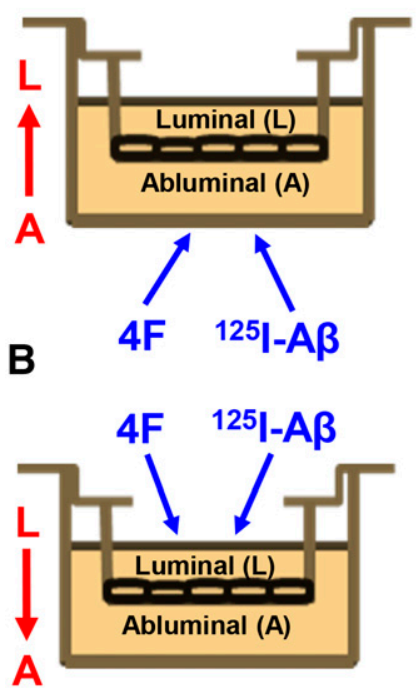

C

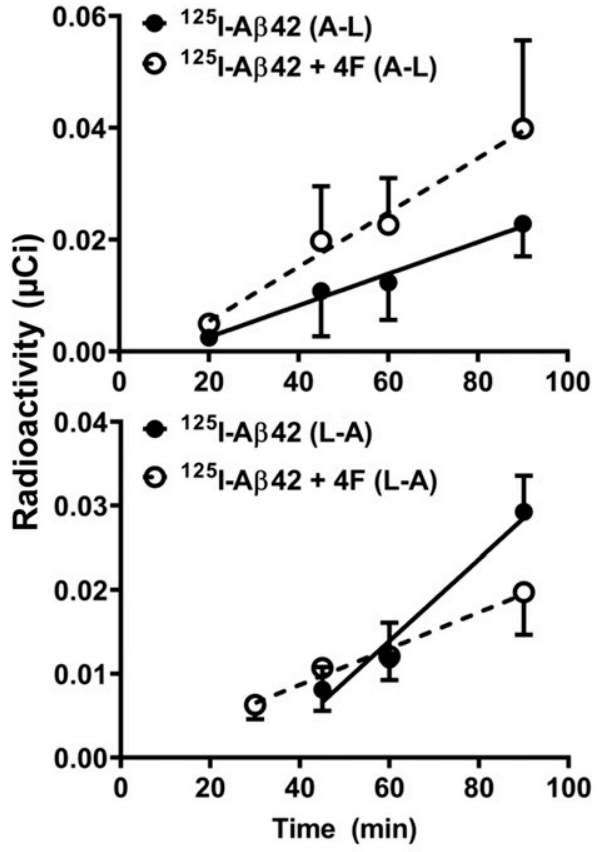

Fig. 5. $4 \mathrm{~F}$ promotes the abluminal-to-luminal flux and inhibits the luminal-to-abluminal flux of $\left[{ }^{125} \mathrm{I}\right] \mathrm{A} \beta 42$ across BBB cell monolayers. Polarized hCMEC/D3 monolayers cultured on Transwell filters were treated with $4 \mathrm{~F}(10 \mu \mathrm{g} /$ $\mathrm{ml})$ and ${ }^{125} \mathrm{I}$ radiolabeled $\mathrm{A} \beta 42(10 \mu \mathrm{Ci} / \mathrm{ml})$ together on the abluminal side to investigate A-L flux (A) or on the luminal side to investigate L-A flux (B). The receiver medium was periodically sampled from the contralateral side, and the radioactivity was measured. Cumulative radioactivity was plotted against time, and the linear region was fit to a linear regression model. Data represent means \pm S.D. $(n=4)$. (C) Flux was obtained by dividing the linear regression slope by the surface area $\left(1.12 \mathrm{~cm}^{2}\right)$ of the insert. Data represent means \pm S.E. $(n=4) .{ }^{*} P<0.05$; unpaired two-tailed $t$ test.

\begin{tabular}{|c|c|c|c|}
\hline & ${ }^{125} \mathrm{I}-\mathrm{A} \beta 42$ & $125 \mathrm{I}-\mathrm{A} \beta 42+4 \mathrm{~F}$ & Signif. \\
\hline$(\mathrm{A}-\mathrm{L})$ Flux $\left(\mu \mathrm{Ci} / \mathrm{min} / \mathrm{cm}^{2} \times 10^{-4}\right)$ & $2.5 \pm 0.3$ & $4.3 \pm 0.4$ & $*$ \\
\hline$(\mathrm{L}-\mathrm{A})$ Flux $\left(\mu \mathrm{Ci} / \mathrm{min} / \mathrm{cm}^{2} \times 10^{-4}\right)$ & $4.3 \pm 0.8$ & $1.9 \pm 0.2$ & $*$ \\
\hline
\end{tabular}

uptake of F-A $\beta 40$ after treatment with $4 \mathrm{~F}$ (Fig. 6B). Further, confocal micrographs depicted lower intracellular accumulation of F-A $\beta 42$ in cells treated with $4 \mathrm{~F}$ (Fig. 6C).

\section{Discussion}

It is well established that plasma ApoA-I levels are strong predictors of cardiovascular risk. Given that CVD and $\mathrm{AD}$ are closely linked, it is likely that decreased serum ApoA-I levels contribute to cerebrovascular dysfunction in $\mathrm{AD}$. This claim is strongly supported by published reports that have demonstrated inverse correlations between plasma ApoA-I levels and $\mathrm{AD}$ risk in elderly patients (Saczynski et al., 2007; Ma et al., 2015; Slot et al., 2017). We previously showed that CAA, the most prevalent cerebrovascular pathology in $\mathrm{AD}$, and cognitive decline could be mitigated by increasing ApoA-I levels in the plasma of AD transgenic mice (Lewis et al., 2010). However, the mechanisms by which ApoA-I promotes cerebrovascular $\mathrm{A} \beta$ clearance and thereby protects from CAA and related neurovascular pathologies are poorly understood.

Our previous studies have shown that increased $\mathrm{A} \beta$ uptake on the luminal side and/or decreased $\mathrm{A} \beta$ efflux from the abluminal side could trigger $\mathrm{A} \beta$ buildup in the cerebral vasculature (Agyare et al., 2013), which is expected to further impede $\mathrm{A} \beta$ clearance from the brain. Hence, it is likely that ApoA-I reduces cerebrovascular $\mathrm{A} \beta$ deposition by modulating $\mathrm{A} \beta$ trafficking machinery at the $\mathrm{BBB}$. Interestingly, ApoA-I on the luminal side was shown to increase $\mathrm{A} \beta$ efflux in the abluminal-to-luminal direction across cerebrovascular endothelial cell monolayers (Merino-Zamorano et al., 2016). However, it remains unclear whether it is ApoA-I in the plasma, in the brain, or both that drive cerebrovascular $\mathrm{A} \beta$ clearance.
Decreased ApoA-I levels in the brain and cerebrospinal fluid are associated with neurologic diseases such as schizophrenia (Huang et al., 2008). ApoA-I is majorly produced in the periphery, with little to no production in the brain (Elliott et al., 2010). Thus, the ApoA-I present in brain is thought to be delivered from systemic circulation via trafficking at the $\mathrm{BBB}$ endothelium and/or the bloodcerebrospinal fluid barrier epithelium. ApoA-I is a large protein, and its permeability at these barriers is extremely low (Stukas et al., 2014; Zhou et al., 2019). Hence, it is important to consider ApoA-I mimetic peptides, like 4F, as therapeutic alternatives. Further, the 18-amino-acid $4 \mathrm{~F}$ peptide is more amenable to pharmaceutical development compared with the full-length ApoA-I protein. As a small, amphipathic peptide that interacts with the plasma membrane (Datta et al., 2001), $4 \mathrm{~F}$ is expected to cross the BBB efficiently. To confirm this in vivo, the PS product, a widely used parameter to assess the brain uptake of macromolecules, was determined after systemic injection of $\left[{ }^{125} \mathrm{I}\right] 4 \mathrm{~F}$ or $\left[{ }^{125} \mathrm{I}\right]$ ApoA-I in mice. The PS values of $\left[{ }^{125} \mathrm{I}\right] 4 \mathrm{~F}$ at various brain regions were $\sim 1000$-fold greater than those determined for $\left[{ }^{125} \mathrm{I}\right] \mathrm{ApoA}-\mathrm{I}$ and were commensurate to that of proteins like transferrin and insulin, which are efficiently delivered across the BBB (Poduslo et al., 1994). In contrast, the PS values of $\left[{ }^{125} \mathrm{I}\right] \mathrm{ApoA}-\mathrm{I}$ were similar to those of proteins that demonstrate very low BBB permeability, such as immunoglobulin $\mathrm{G}$ and albumin (Poduslo et al., 1994). The efficient brain penetrance of $4 \mathrm{~F}$ provides a plausible mechanistic interpretation of the robust $4 \mathrm{~F}$ effects on neuropathology in $\mathrm{AD}$ mice. Given that PS values are representative only of influx, the impact of $4 \mathrm{~F}$ brain efflux on the overall brain delivery remains to be clarified. 

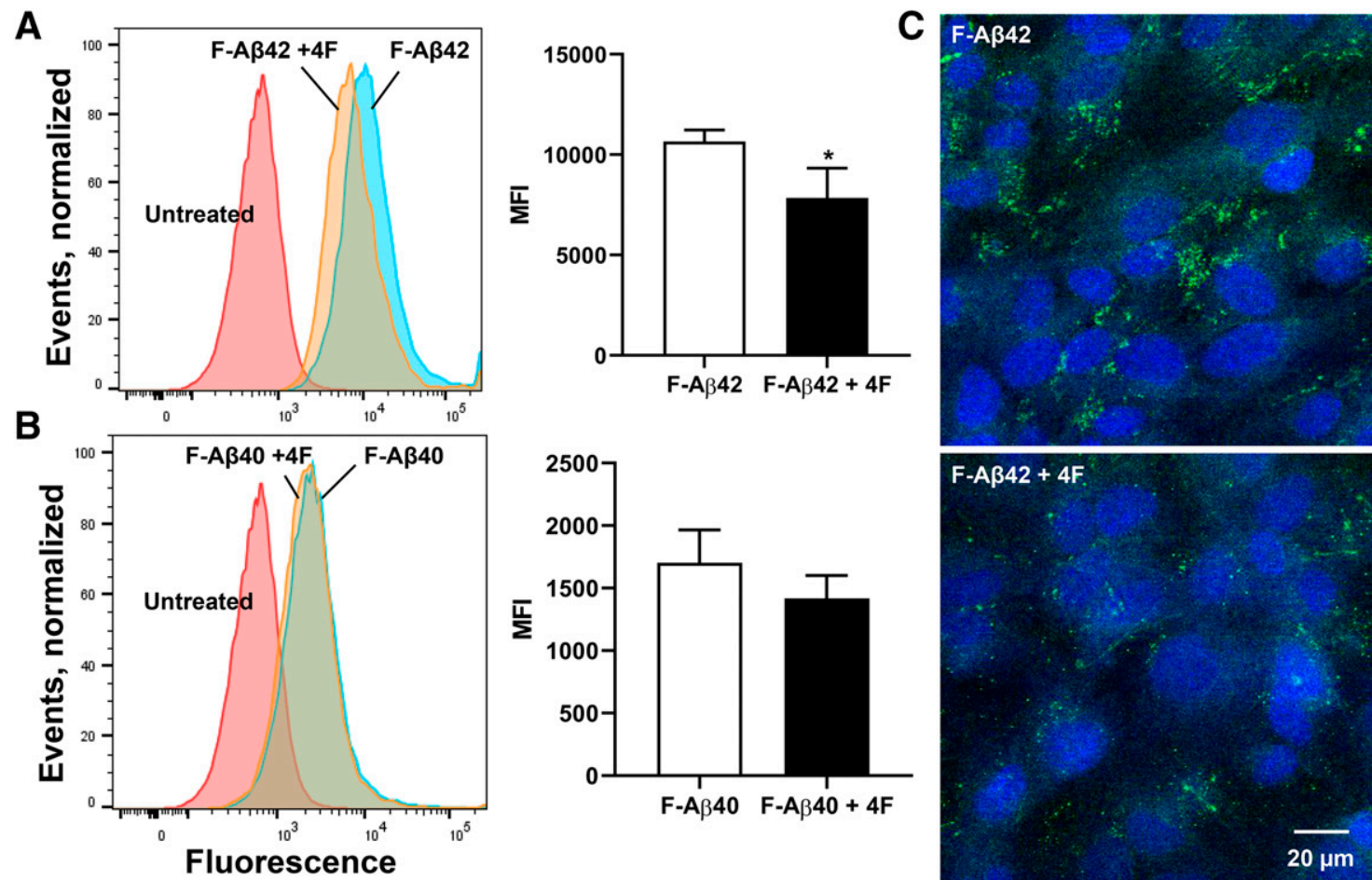

Fig. 6. $4 \mathrm{~F}$ inhibits the accumulation of fluorescein-labeled $\mathrm{A} \beta 42$ in $\mathrm{BBB}$ cell monolayers. hCMEC/D3 monolayers were treated for 60 minutes with 10 $\mu \mathrm{g} / \mathrm{ml} 4 \mathrm{~F}$ peptide, followed by another 60 minutes with $12.5 \mu \mathrm{g} / \mathrm{ml}$ of fluorescein-labeled A $\beta 42$ (F-A $\beta 42)$ (A) or F-A $\beta 40$ (B). The fluorescence uptake was assessed by flow cytometry. Shown are representative histograms and bar charts of the group means \pm S.D. $(n=3)$. $* P<0.05$; unpaired two-tailed $t$ test. (C) Confocal micrographs are shown depicting F-A $\beta 42$ internalization in hCMEC/D3 monolayers cultured on coverslip dishes after $4 \mathrm{~F}$ treatment as described above (representative images, $n=3$ ). Green $=\mathrm{F}$-A $\beta 42$; blue $=4^{\prime}, 6$-diamidino-2-phenylindole-stained nuclei

Further, we investigated the ability of $4 \mathrm{~F}$ to modulate $\mathrm{A} \beta$ trafficking from brain to blood and from blood to brain. To assess $4 \mathrm{~F}^{\prime}$ 's effect on $\left[{ }^{125} \mathrm{I}\right] \mathrm{A} \beta 42$ clearance from brain to blood, the $\left[{ }^{125} \mathrm{I}\right] \mathrm{A} \beta 42$ radioactivity retained in the brain after intracerebral injection was assessed in mice infused with $4 \mathrm{~F}$ via the internal carotid artery, which supplies blood directly to the brain. This experimental modality allowed us to specifically investigate $4 \mathrm{~F}$ 's effects on $\left.{ }^{125} \mathrm{I}\right] \mathrm{A} \beta 42$ transport at the $\mathrm{BBB}$. The brain retention of $\left[{ }^{125} \mathrm{I}\right] \mathrm{A} \beta 42$ was substantially decreased in $4 \mathrm{~F}$-treated mice, which could be attributed to increased $\left[{ }^{125} \mathrm{I}\right] \mathrm{A} \beta 42$ brain efflux. It was also observed that after femoral injection, the brain influx of $\left[{ }^{125} \mathrm{I}\right] \mathrm{A} \beta 42$, assessed as the PS product, was substantially decreased in $4 \mathrm{~F}$-treated mice. Together, these findings indicate that $4 \mathrm{~F}$ reduces the brain accumulation of $\left[{ }^{125} \mathrm{I}\right] \mathrm{A} \beta 42$ by increasing its brain-to-blood efflux and by decreasing its blood-to-brain influx. Intriguingly, $4 \mathrm{~F}$ exhibited distinct effects in modulating the brain influx of $\left[{ }^{125} \mathrm{I}\right] \mathrm{A} \beta 40$ as compared with $\left[{ }^{125} \mathrm{I}\right] \mathrm{A} \beta 42$; a nonsignificant increase in $\left[{ }^{125} \mathrm{I}\right] \mathrm{A} \beta 40$ brain influx was observed in the $4 \mathrm{~F}$ treated mice. Importantly, $A \beta 42$ is considered to be more neurotoxic and amyloidogenic than $\mathrm{A} \beta 40$, and parenchymal amyloid plaques in $\mathrm{AD}$ brain are seeded by $\mathrm{A} \beta 42$ aggregates (Miller et al., 1993). Additionally, $A \beta 40$ is reported to inhibit $\mathrm{A} \beta 42$ oligomerization, fibrillogenesis, and toxicity (Jan et al., 2008; Murray et al., 2009). In patients with $\mathrm{AD}$, the accelerated amyloid accumulation in the cerebral vasculature and brain parenchyma is thought to be majorly due to the impaired A $\beta 42$ clearance from brain to blood (Sagare et al., 2012). By helping to restore $\mathrm{A} \beta 42$ clearance at the $\mathrm{BBB}, 4 \mathrm{~F}$ could thereby reduce both cerebrovascular and parenchymal amyloid burden in $\mathrm{AD}$ brain.
No significant differences were observed in the $\left[{ }^{125} \mathrm{I}\right] \mathrm{A} \beta 42$ plasma pharmacokinetics in $4 \mathrm{~F}$-treated mice, although a visual trend of increased AUC with a concomitant decrease in terminal clearance was observed. The apparent decrease in plasma clearance of $\left[{ }^{125} \mathrm{I}\right] \mathrm{A} \beta 42$ in the presence of $4 \mathrm{~F}$ could be due to altered $\mathrm{A} \beta 42$ clearance mechanisms in kidneys and liver, which represent the major organs responsible for systemic A $\beta$ clearance (Ghiso et al., 2004). Since the plasma disposition of $\mathrm{A} \beta$ and its trafficking at the $\mathrm{BBB}$ are thought to be handled by low-density lipoprotein receptor-related protein 1 (LRP1) and scavenger receptor class B type 1 (Martins et al., 2009; Thanopoulou et al., 2010), both of which are highly expressed in the vascular endothelium, we speculate that $4 \mathrm{~F}$ modulates $\mathrm{A} \beta$ disposition by interacting with these receptors. It was previously shown that HDL transcytosis at the BBB is mediated by scavenger receptor class B type 1 (Fung et al., 2017). Furthermore, ATP-binding cassette transporter A1 (ABCA1), expressed on the abluminal surface of the BBB endothelium, was shown to mediate the brain efflux of $\mathrm{A} \beta 42$ (Elali and Rivest, 2013). As a major lipid transporter, ABCA1 interacts with HDL/ApoA-I and other apolipoproteins that mediate lipid efflux and reverse cholesterol transport. Studies have shown that ABCA1 overexpression mitigates, whereas $\mathrm{ABCA} 1$ deletion exacerbates, brain $\mathrm{A} \beta$ deposition in $\mathrm{AD}$ mice (Wahrle et al., 2005, 2008). We recently showed that $4 \mathrm{~F}$ interacts with ABCA1 to mediate cholesterol/lipid efflux (Chernick et al., 2018). Thus, the altered brain influx of $\left[{ }^{125} \mathrm{I}\right] \mathrm{A} \beta 42$ upon $4 \mathrm{~F}$ treatment could potentially be mediated by effects on $\mathrm{ABCA} 1$ at the BBB.

Since only female mice were used in this study, further studies are needed to examine potential sex differences in $4 \mathrm{~F}$ 
efficacy. In various $\mathrm{AD}$ transgenic mouse models, such as 3xTg-AD (Carroll et al., 2010; Gali et al., 2019), APP/PS1, and Tg2576 mice (Callahan et al., 2001), female mice were reported to exhibit higher $\mathrm{A} \beta$ levels and greater occurrence of histopathological hallmarks compared with their male littermates. Moreover, sex differences were also apparent in the efficacy of experimental $\mathrm{AD}$ therapies that mitigate $\mathrm{A} \beta$ pathology (Long et al., 2016; Dodiya et al., 2019). In this study, experiments were conducted solely on female mice so that follow-up studies can be pursued in female APP/PS1 mice, which are reported to manifest higher $\mathrm{A} \beta$ levels compared with the male mice. The APP/PS1 mice will serve as a more stringent model to test the efficacy and mechanistic action of $4 \mathrm{~F}$.

To verify the in vivo findings, we investigated $\left[{ }^{125} \mathrm{I}\right] \mathrm{A} \beta 42$ transcytosis in both directions across $\mathrm{BBB}$ cell monolayers cultured on Transwell filters. Treatment with $4 \mathrm{~F}$ was shown to increase the abluminal-to-luminal flux of $\left[{ }^{125} \mathrm{I}\right] \mathrm{A} \beta 42$, which is consistent with the increased brain efflux of $\left[{ }^{125} \mathrm{I}\right] \mathrm{A} \beta 42$ observed in $4 \mathrm{~F}$-treated mice. We further showed that $4 \mathrm{~F}$ decreased the luminal-to-abluminal flux of $\left[{ }^{125} \mathrm{I}\right] \mathrm{A} \beta 42$, which is consistent with the decreased brain influx of $\left[{ }^{125} \mathrm{I}\right] \mathrm{A} \beta 42$ observed in 4F-treated mice. Together, these findings indicate that $4 \mathrm{~F}$ differentially modulates $\left[{ }^{125} \mathrm{I}\right] \mathrm{A} \beta 42$ trafficking at the $\mathrm{BBB}$ in the luminal-to-abluminal (blood to brain) versus abluminal-to-luminal (brain to blood) directions.

To investigate the effects of $4 \mathrm{~F}$ on cerebrovascular accumulation of $\mathrm{A} \beta$, which predominates in both $\mathrm{CAA}$ and $\mathrm{AD}$, we evaluated the cellular uptake of fluorescein-labeled $\mathrm{A} \beta$ in BBB cell monolayers after $4 \mathrm{~F}$ treatment. When assessed by flow cytometry, the uptake of F-A $\beta 42$ was found to be decreased in $4 \mathrm{~F}$-treated cells, whereas the F-A $\beta 40$ uptake was not significantly altered. Using laser confocal microscopy, we also demonstrated lower intracellular accumulation of F-A $\beta 42$ in $4 \mathrm{~F}$-treated cells. Although $\mathrm{A} \beta 40$ is the predominant isoform present in the cerebrovascular amyloid deposits, A $\beta 42$ was shown to seed the formation of these deposits (Roher et al., 1993; McGowan et al., 2005). Thus, $4 \mathrm{~F}$ could be effective in reducing cerebrovascular $\mathrm{A} \beta$ deposition in $\mathrm{CAA}$ and $\mathrm{AD}$.

In summary, the brain permeability of $\left[{ }^{125} \mathrm{I}\right] 4 \mathrm{~F}$, assessed as the PS product, was found to be $\sim 1000$-fold greater than that of $\left[{ }^{125} \mathrm{I}\right] \mathrm{ApoA}-\mathrm{I}$ and was comparable to proteins like transferrin and insulin, which rapidly permeate across the BBB. Moreover, systemic infusion of $4 \mathrm{~F}$ was shown to modulate the $\mathrm{BBB}$ trafficking of $\left[{ }^{125} \mathrm{I}\right] \mathrm{A} \beta 42$ by increasing its brain-to-blood efflux and by decreasing its blood-to-brain influx. These findings clarify the effects of $4 \mathrm{~F}$ on specific $\mathrm{A} \beta$ isoforms and provide a mechanistic interpretation of the decreased brain $\mathrm{A} \beta$ deposition reported in $\mathrm{AD}$ transgenic mice after chronic oral dosing of $4 \mathrm{~F}$ (Handattu et al., 2009). However, it remains unclear whether $4 \mathrm{~F}$ elicits these beneficial effects by acting on the luminal side or by acting within the brain parenchyma after crossing the BBB. Further studies are needed to clarify the molecular mechanisms by which $4 \mathrm{~F}$ alleviates $\mathrm{A} \beta$-associated neuropathologies in $\mathrm{CAA}$ and $\mathrm{AD}$. Although clinical efficacy of $4 \mathrm{~F}$ was demonstrated in patients with CVD (Bloedon et al., 2008; Dunbar et al., 2017), the efficacy of $4 \mathrm{~F}$ in treating patients with $\mathrm{AD}$ remains to be carefully elucidated, especially in the perspective of challenges encountered in the clinical translation of anti-A $\beta$ therapeutics. Nevertheless, as an ApoA-I/HDL mimetic peptide, $4 \mathrm{~F}$ also possesses antioxidative and inflammatory properties and thus presents a novel therapeutic approach to enhance cerebrovascular function as well as to mitigate brain $\mathrm{A} \beta$ accumulation in $\mathrm{CAA}$ and $\mathrm{AD}$.

\section{Authorship Contributions}

Participated in research design: Swaminathan, Zhou, Ahlschwede,

$\mathrm{Li}$, Kandimalla.

Conducted experiments: Swaminathan, Zhou, Ahlschwede, Curran. Contributed new reagents or analytic tools: $\mathrm{Li}$.

Performed data analysis: Swaminathan, Zhou, Ahlschwede, Kandimalla.

Wrote or contributed to the writing of the manuscript: Swaminathan, Zhou, Lowe, Li, Kandimalla.

\section{References}

Agyare EK, Leonard SR, Curran GL, Yu CC, Lowe VJ, Paravastu AK, Poduslo JF, and Kandimalla KK (2013) Traffic jam at the blood-brain barrier promotes greater accumulation of Alzheimer's disease amyloid- $\beta$ proteins in the cerebral vasculature. Mol Pharm 10:1557-1565.

Anantharamaiah GM, Mishra VK, Garber DW, Datta G, Handattu SP, Palgunachari MN, Chaddha M, Navab M, Reddy ST, Segrest JP, et al. (2007) Structura requirements for antioxidative and anti-inflammatory properties of apolipoprotein A-I mimetic peptides. J Lipid Res 48:1915-1923.

Assmann G and Gotto AM Jr. (2004) HDL cholesterol and protective factors in atherosclerosis. Circulation 109 (Suppl 1):III8-III14.

Bloedon LT, Dunbar R, Duffy D, Pinell-Salles P, Norris R, DeGroot BJ, Movva R Navab M, Fogelman AM, and Rader DJ (2008) Safety, pharmacokinetics, and pharmacodynamics of oral apoA-I mimetic peptide D-4F in high-risk cardiovascular patients. J Lipid Res 49:1344-1352.

Buga GM, Frank JS, Mottino GA, Hendizadeh M, Hakhamian A, Tillisch JH, Reddy ST, Navab M, Anantharamaiah GM, Ignarro LJ, et al. (2006) D-4F decreases brain arteriole inflammation and improves cognitive performance in LDL receptor-null mice on a Western diet. J Lipid Res 47:2148-2160.

Button EB, Robert J, Caffrey TM, Fan J, Zhao W, and Wellington CL (2019) HDL from an Alzheimer's disease perspective. Curr Opin Lipidol 30:224-234

Callahan MJ, Lipinski WJ, Bian F, Durham RA, Pack A, and Walker LC (2001) Augmented senile plaque load in aged female beta-amyloid precursor proteintransgenic mice. Am J Pathol 158:1173-1177.

Carroll JC, Rosario ER, Kreimer S, Villamagna A, Gentzschein E, Stanczyk FZ, and Pike CJ (2010) Sex differences in $\beta$-amyloid accumulation in 3xTg-AD mice: role of neonatal sex steroid hormone exposure. Brain Res 1366:233-245.

Charidimou A, Gang Q, and Werring DJ (2012) Sporadic cerebral amyloid angiopathy revisited: recent insights into pathophysiology and clinical spectrum. J Neurol Neurosurg Psychiatry 83:124-137.

Chernick D, Ortiz-Valle S, Jeong A, Swaminathan SK, Kandimalla KK, Rebeck GW, and $\mathrm{Li} \mathrm{L}$ (2018) High-density lipoprotein mimetic peptide $4 \mathrm{~F}$ mitigates amyloid$\beta$-induced inhibition of apolipoprotein $\mathrm{E}$ secretion and lipidation in primary astrocytes and microglia. J Neurochem 147:647-662.

Datta G, Chaddha M, Hama S, Navab M, Fogelman AM, Garber DW, Mishra VK, Epand RM, Epand RF, Lund-Katz S, et al. (2001) Effects of increasing hydrophobicity on the physical-chemical and biological properties of a class A amphipathic helical peptide. J Lipid Res 42:1096-1104.

Dodiya HB, Kuntz T, Shaik SM, Baufeld C, Leibowitz J, Zhang X, Gottel N, Zhang X, Butovsky O, Gilbert JA, et al. (2019) Sex-specific effects of microbiome perturbations on cerebral A $\beta$ amyloidosis and microglia phenotypes. J Exp Med 216: $1542-1560$.

Dunbar RL, Movva R, Bloedon LT, Duffy D, Norris RB, Navab M, Fogelman AM, and Rader DJ (2017) Oral apolipoprotein A-I mimetic D-4F lowers HDLinflammatory index in high-risk patients: a first-in-human multiple-dose, randomized controlled trial. Clin Transl Sci 10:455-469.

Elali A and Rivest S (2013) The role of ABCB1 and ABCA1 in beta-amyloid clearance at the neurovascular unit in Alzheimer's disease. Front Physiol 4:45.

Elliott DA, Weickert CS, and Garner B (2010) Apolipoproteins in the brain: implications for neurological and psychiatric disorders. Clin Lipidol 51:555-573.

Fagan AM, Christopher E, Taylor JW, Parsadanian M, Spinner M, Watson M, Fryer JD, Wahrle S, Bales KR, Paul SM, et al. (2004) ApoAI deficiency results in marked reductions in plasma cholesterol but no alterations in amyloid-beta pathology in a mouse model of Alzheimer's disease-like cerebral amyloidosis. Am J Pathol 165: 1413-1422.

Fung KY, Wang C, Nyegaard S, Heit B, Fairn GD, and Lee WL (2017) SR-BI mediated transcytosis of HDL in brain microvascular endothelial cells is independent of caveolin, clathrin, and PDZK1. Front Physiol 8:841.

Gali CC, Fanaee-Danesh E, Zandl-Lang M, Albrecher NM, Tam-Amersdorfer C, Stracke A, Sachdev V, Reichmann F, Sun Y, Avdili A, et al. (2019) Amyloid-beta impairs insulin signaling by accelerating autophagy-lysosomal degradation of LRP- 1 and IR- $\beta$ in blood-brain barrier endothelial cells in vitro and in 3XTg-AD mice. Mol Cell Neurosci 99:103390.

Ghiso J, Shayo M, Calero M, Ng D, Tomidokoro Y, Gandy S, Rostagno A and Frangione B (2004) Systemic catabolism of Alzheimer's Abeta40 and Abeta42. $J$ Biol Chem 279:45897-45908.

Handattu SP, Garber DW, Monroe CE, van Groen T, Kadish I, Nayyar G, Cao D, Palgunachari MN, Li L, and Anantharamaiah GM (2009) Oral apolipoprotein A-I mimetic peptide improves cognitive function and reduces amyloid burden in a mouse model of Alzheimer's disease. Neurobiol Dis 34:525-534. 
Herzig MC, Van Nostrand WE, and Jucker M (2006) Mechanism of cerebral betaamyloid angiopathy: murine and cellular models. Brain Pathol 16:40-54.

Hottman DA, Chernick D, Cheng S, Wang Z, and Li L (2014) HDL and cognition in neurodegenerative disorders. Neurobiol Dis 72:22-36.

Huang JT, Wang L, Prabakaran S, Wengenroth M, Lockstone HE, Koethe D, Gerth CW, Gross S, Schreiber D, Lilley K, et al. (2008) Independent protein-profiling studies show a decrease in apolipoprotein A1 levels in schizophrenia CSF, brain and peripheral tissues. Mol Psychiatry 13:1118-1128.

Jan A, Gokce O, Luthi-Carter R, and Lashuel HA (2008) The ratio of monomeric to aggregated forms of Abeta 40 and Abeta42 is an important determinant of amyloidbeta aggregation, fibrillogenesis, and toxicity. J Biol Chem 283:28176-28189.

Jaruszewski KM, Curran GL, Swaminathan SK, Rosenberg JT, Grant SC, Ramakrishnan S, Lowe VJ, Poduslo JF, and Kandimalla KK (2014) Multimodal nanoprobes to target cerebrovascular amyloid in Alzheimer's disease brain. Biomaterials 35:1967-1976.

Kandimalla KK, Wengenack TM, Curran GL, Gilles EJ, and Poduslo JF (2007) Pharmacokinetics and amyloid plaque targeting ability of a novel peptide-based magnetic resonance contrast agent in wild-type and Alzheimer's disease transgenic mice. J Pharmacol Exp Ther 322:541-549.

Lefterov I, Fitz NF, Cronican AA, Fogg A, Lefterov P, Kodali R, Wetzel R, and Koldamova R (2010) Apolipoprotein A-I deficiency increases cerebral amyloid angiopathy and cognitive deficits in APP/PS1DeltaE9 mice. J Biol Chem 285 36945-36957.

Lewis TL, Cao D, Lu H, Mans RA, Su YR, Jungbauer L, Linton MF, Fazio S, LaDu MJ, and Li L (2010) Overexpression of human apolipoprotein A-I preserves cognitive function and attenuates neuroinflammation and cerebral amyloid angiopathy in a mouse model of Alzheimer disease. J Biol Chem 285:36958-36968.

Long Z, Zeng Q, Wang K, Sharma A, and He G (2016) Gender difference in valproic acid-induced neuroprotective effects on APP/PS1 double transgenic mice modeling Alzheimer's disease. Acta Biochim Biophys Sin (Shanghai) 48:930-938.

Ma C, Li J, Bao Z, Ruan Q, and Yu Z (2015) Serum levels of ApoA1 and ApoA2 are associated with cognitive status in older men. BioMed Res Int 2015:481621.

Martins IJ, Berger T, Sharman MJ, Verdile G, Fuller SJ, and Martins RN (2009) Cholesterol metabolism and transport in the pathogenesis of Alzheimer's disease. $J$ Neurochem 111:1275-1308.

McGowan E, Pickford F, Kim J, Onstead L, Eriksen J, Yu C, Skipper L, Murphy MP, Beard J, Das P, et al. (2005) Abeta42 is essential for parenchymal and vascular amyloid deposition in mice. Neuron 47:191-199.

Merino-Zamorano C, Fernández-de Retana S, Montañola A, Batlle A, Saint-Pol J, Mysiorek C, Gosselet F, Montaner J, and Hernández-Guillamon M (2016) Modulation of amyloid- $\beta 1-40$ transport by ApoA1 and ApoJ across an in vitro model of the blood-brain barrier. J Alzheimers Dis 53:677-691.

Michaud JP, Bellavance MA, Préfontaine P, and Rivest S (2013a) Real-time in vivo imaging reveals the ability of monocytes to clear vascular amyloid beta. Cell Rep $\mathbf{5}$ : 646-653.

Michaud JP, Hallé M, Lampron A, Thériault P, Préfontaine P, Filali M, Tribout-Jover $\mathrm{P}$, Lanteigne AM, Jodoin R, Cluff C, et al. (2013b) Toll-like receptor 4 stimulation with the detoxified ligand monophosphoryl lipid A improves Alzheimer's diseaserelated pathology. Proc Natl Acad Sci USA 110:1941-1946.

Miller DL, Papayannopoulos IA, Styles J, Bobin SA, Lin YY, Biemann K, and Iqbal K (1993) Peptide compositions of the cerebrovascular and senile plaque core amyloid deposits of Alzheimer's disease. Arch Biochem Biophys 301:41-52.

Morgantini C, Imaizumi S, Grijalva V, Navab M, Fogelman AM, and Reddy ST (2010) Apolipoprotein A-I mimetic peptides prevent atherosclerosis development and reduce plaque inflammation in a murine model of diabetes. Diabetes 59:3223-3228.

Murray MM, Bernstein SL, Nyugen V, Condron MM, Teplow DB, and Bowers MT (2009) Amyloid beta protein: abeta40 inhibits Abeta42 oligomerization. J Am Chem Soc 131:6316-6317.

Navab M, Shechter I, Anantharamaiah GM, Reddy ST, Van Lenten BJ, and Fogelman AM (2010) Structure and function of HDL mimetics. Arterioscler Thromb Vasc Biol 30:164-168.
Poduslo JF, Curran GL, and Berg CT (1994) Macromolecular permeability across the blood-nerve and blood-brain barriers. Proc Natl Acad Sci USA 91: 5705-5709.

Poduslo JF, Curran GL, Wengenack TM, Malester B, and Duff K (2001) Permeability of proteins at the blood-brain barrier in the normal adult mouse and double transgenic mouse model of Alzheimer's disease. Neurobiol Dis 8:555-567.

Qi XM and Ma JF (2017) The role of amyloid beta clearance in cerebral amyloid angiopathy: more potential therapeutic targets. Transl Neurodegener 6:22.

Roher AE, Lowenson JD, Clarke S, Woods AS, Cotter RJ, Gowing E, and Ball MJ (1993) beta-Amyloid-(1-42) is a major component of cerebrovascular amyloid deposits: implications for the pathology of Alzheimer disease. Proc Natl Acad Sci USA 90:10836-10840.

Saczynski JS, White L, Peila RL, Rodriguez BL, and Launer LJ (2007) The relation between apolipoprotein A-I and dementia: the Honolulu-Asia aging study. Am $J$ Epidemiol 165:985-992.

Sagare AP, Bell RD, and Zlokovic BV (2012) Neurovascular dysfunction and faulty amyloid $\beta$-peptide clearance in Alzheimer disease. Cold Spring Harb Perspect Med 2:a011452

Slot RE, Van Harten AC, Kester MI, Jongbloed W, Bouwman FH, Teunissen CE Scheltens P, Veerhuis R, and van der Flier WM (2017) Apolipoprotein A1 in cerebrospinal fluid and plasma and progression to Alzheimer's disease in nondemented elderly. J Alzheimers Dis 56:687-697.

Smith AD (2002) Imaging the progression of Alzheimer pathology through the brain. Proc Natl Acad Sci USA 99:4135-4137.

Stukas S, Robert J, Lee M, Kulic I, Carr M, Tourigny K, Fan J, Namjoshi D, Lemke K, DeValle N, et al. (2014) Intravenously injected human apolipoprotein A-I rapidly enters the central nervous system via the choroid plexus. J Am Heart Assoc 3 e001156.

Swaminathan SK, Ahlschwede KM, Sarma V, Curran GL, Omtri RS, Decklever T, Lowe VJ, Poduslo JF, and Kandimalla KK (2018) Insulin differentially affects the distribution kinetics of amyloid beta 40 and 42 in plasma and brain. J Cereb Blood Flow Metab 38:904-918.

Thanopoulou K, Fragkouli A, Stylianopoulou F, and Georgopoulos S (2010) Scavenger receptor class B type I (SR-BI) regulates perivascular macrophages and modifies amyloid pathology in an Alzheimer mouse model. Proc Natl Acad Sci USA 107:20816-20821.

Viswanathan A and Greenberg SM (2011) Cerebral amyloid angiopathy in the elderly. Ann Neurol 70:871-880.

Wahrle SE, Jiang H, Parsadanian M, Hartman RE, Bales KR, Paul SM, and Holtzman DM (2005) Deletion of Abca1 increases Abeta deposition in the PDAPP transgenic mouse model of Alzheimer disease. J Biol Chem 280: $43236-43242$

Wahrle SE, Jiang H, Parsadanian M, Kim J, Li A, Knoten A, Jain S, Hirsch-Reinshagen V, Wellington CL, Bales KR, et al. (2008) Overexpression of ABCA1 reduces amyloid deposition in the PDAPP mouse model of Alzheimer disease. J Clin Invest 118:671-682.

Weksler B, Romero IA, and Couraud PO (2013) The hCMEC/D3 cell line as a model of the human blood brain barrier. Fluids Barriers CNS 10:16.

Yamada M and Naiki H (2012) Cerebral amyloid angiopathy. Prog Mol Biol Transl Sci 107:41-78.

Zhou AL, Swaminathan SK, Curran GL, Poduslo JF, Lowe VJ, Li L, and Kandimalla KK (2019) Apolipoprotein A-I crosses the blood-brain barrier through clathrinindependent and cholesterol-mediated endocytosis. J Pharmacol Exp Ther 369: 481-488.

Address correspondence to: Dr. Karunya K. Kandimalla, Department of Pharmaceutics, Brain Barriers Research Center, University of Minnesota College of Pharmacy, 9-149A, Weaver-Densford Hall, 308 Harvard St. SE, Minneapolis, MN 55455. E-mail: kkandima@umn.edu 